\title{
The toxicity of benzene and its metabolism and molecular pathology in human risk assessment
}

\author{
A Yardley-Jones, D Anderson, D V Parke
}

\begin{abstract}
Benzene, a common industrial chemical and a component of gasoline, is radiomimetic and exposure may lead progressively to aplastic anaemia, leukaemia, and multiple myeloma. Although benzene has been shown to cause many types of genetic damage, it has consistently been classified as a non-mutagen in the Ames test, possibly because of the inadequacy of the $\mathbf{S 9}$ microsomal activation system. The metabolism of benzene is complex, yielding glucuronide and sulphate conjugates of phenol, quinol, and catechol, L-phenylmercapturic acid, and muconaldehyde and trans, transmuconic acid by ring scission. Quinol is oxidised to p-benzoquinone, which binds to vital cellular components or undergoes redox cycling to generate oxygen radicals; muconaldehyde, like p-benzoquinone, is toxic through depletion of intracellular glutathione. Exposure to benzene may also induce the microsomal mixed function oxidase, cytochrome P450 IIE1, which is probably responsible for the oxygenation of benzene, but also has a propensity to generate oxygen radicals. The radiomimetic nature of benzene and its ability to induce different sites of neoplasia indicate that formation of oxygen radicals is a major cause of benzene toxicity, which involves multiple mechanisms including synergism between arylating and glutathione-depleting reactive metabolites and oxygen radicals. The occupational exposure limit in the United Kingdom (MEL) and the United States (PEL) was $10 \mathrm{ppm}$ based on the association of benzene exposure with aplastic anaemia, but recently was lowered to $5 \mathrm{ppm}$ and $1 \mathrm{ppm}$ respectively,
\end{abstract}

Department of Biochemistry, University of Surrey, Guildford, Surrey GU2 5XH, UK

A Yardley-Jones, D V Parke

The British Industrial Biological Research Association, Woodmansterne Road, Carshalton, Surrey SM5 4DS

D Anderson

Burmah Castrol Trading Ltd, Burmah Castrol House, Pipers Way, Swindon, Wiltshire SN3 1RE A Yardley-Jones reflecting a concern for the risk of neoplasia. The American Conference of Governmental Industrial Hygienists (ACGIH) has even more recently recommended that, as benzene is considered an A1 carcinogen, the threshold limit value (TLV) should be decreased to $0.1 \mathrm{ppm}$. Only one study in man, based on nine cases of benzene associated fatal neoplasia, has been considered suitable for risk assessment. Recent re-evaluation of these data indicated that past assessments may have overestimated the risk, and different authors have considered that lifetime exposure to benzene at $1 \mathrm{ppm}$ would result in an excess of leukaemia deaths of 0.5 to 1.0 per 1000 . Although in this study, deaths at low levels of benzene exposure were associated with multiple myeloma and a long latency period, instead of leukaemia, which might justify further lowering of the exposure limit, the risk assessment model has been found to be non-significant for response at low levels of exposure. The paucity of data for man, the complexity of the metabolic activation of benzene, the interactive and synergistic mechanisms of benzene toxicity and carcinogenicity, the different disease endpoints (aplastic anaemia, leukaemia, and multiple myeloma), and different individual susceptibilities, all indicate that in such a complex scenario, regulators should proceed with caution before making further changes to the exposure limit for this chemical.

Benzene, a common industrial chemical, a component of gasoline, and a constituent of engine emissions and tobacco smoke, ${ }^{1}$ has a production rate of 15 million tonnes per year, with a total global cycle of 32 million tonnes per year. Benzene is ubiquitous in the environment, and chronically exposed populations include petrochemical workers, petrol station attendants, and smokers. ${ }^{2}$ Benzene is a radiomimetic chemical, with heavy exposure resulting in progressive degeneration of the bone marrow, aplastic anaemia, and leukaemia, and in dysfunction of the immune system. ${ }^{3}$ In 1971 the United States Occupational Safety and Health Administration (OSHA) introduced a permissible exposure limit 
(PEL) of $10 \mathrm{ppm}$, based on the concern for benzene causing aplastic anaemia and myelosuppression, ${ }^{4}$ which was later lowered to $1 \mathrm{ppm}$ based on the concern for the risk of benzene associated neoplasia. ${ }^{4}$ The American Conference of Governmental Industrial Hygienists (ACGIH) has recently proposed that benzene be listed as an A1 confirmed human carcinogen with an eight hour time weighted average threshold limit value (TLV) of $0 \cdot 1 \mathrm{ppm}$ and a skin notation (1990-1991 TLV Notice of Intended Changes). ${ }^{5}$

\section{Benzene toxicity}

Since Delore and Borgomano in $1928^{6}$ first suggested an association between occupational exposure to benzene and the development of leukaemia, it has been generally agreed that a causal relation exists between high exposures to benzene and the development of pancytopaenia, aplastic anaemia, and acute mylogenous leukaemia; a pattern consistent with toxic myelosuppression. ${ }^{78} \mathrm{~A}$ review of the relevant clinical publications concluded that benzene related haemotoxicity in man was associated with benzene concentrations in the workplace of $>50 \mathrm{ppm}$; no evidence of haemotoxicity was reported to be associated with prolonged exposure to benzene concentrations of $20-25 \mathrm{ppm}^{9}$

As well as its haemotoxicity, benzene is considered to be a Group I carcinogen; sufficient evidence of carcinogenicity in man and in laboratory animals. ${ }^{10}$ The association between long term exposure to benzene and the occurrence of leukaemia ${ }^{6}$ was supported by the epidemiological evidence of Viglian $i^{11}$ and more recently by the Bologna experiments, which have shown that benzene is a multipotential carcinogen increasing the incidence of a wide variety of neoplasms in rats and mice. ${ }^{12}$ Studies by the National Cancer Institute and in the National Toxicology Program have shown that benzene induces a larger number of unique sites of neoplasia than any other chemical. ${ }^{45}$ These findings of neoplasia, haemotoxicity, and myelosuppression are indicative of the radiomimetic properties of benzene, and consequently of its potential for oxygen radical generation. The firm evidence of carcinogenic potential in rodents ${ }^{4}$ led OSHA to lower the permissible level of occupational exposure from $10 \mathrm{ppm}$ to $1 \mathrm{ppm}$.

Benzene has produced many types of genetic damage, but although it has caused chromosomal aberrations in animals and man and sister chromatid exchanges and micronuclei both in vitro and in vivo, and has also produced aneuploidy in dividing cells, it has not consistently produced point mutations in genotoxicity test systems. ${ }^{513}$ Benzene itself has not consistently produced mutagenic effects in conventional agar plate techniques for bacterial mutagens.
This is possibly because of the inadequacy of Aroclor induction to produce an appropriate spectrum of the cytochromes P450 to metabolically activate benzene to mutagenic products. ${ }^{5}$ The benzene metabolites, quinol, p-benzoquinone, and trans, trans-muconaldehyde (the most cytotoxic metabolites of benzene ${ }^{14}$ ) showed very weak mutagenic effects in bacteria, but were strongly mutagenic in Chinese hamster V79 cells, mouse L5178Y cells, ${ }^{15}$ and cultured human lymphocytes, ${ }^{1617}$ and induced an increase in sister chromatid exchanges and a decrease in mitotic index in mice in vivo. ${ }^{18} 19$ The little known metabolite of benzene, the anti-diol epoxide, which is a poor substrate for epoxide hydrase, showed, however, a broad spectrum of genotoxicity in bacterial and mammalian cells. ${ }^{20}$

Studies of developmental toxicity have generally failed to show any significant adverse effects of exposure to benzene in rodents or rabbits.

\section{Metabolism of benzene}

The earliest studies of the metabolism of benzene, undertaken by Baumann and others more than a century ago, showed that it was metabolised mostly by oxidation to phenol, quinol, and catechol, which were excreted in the urine as sulphates and glucuronides. ${ }^{21}$ Later studies showed that L-phenylmercapturic acid and trans-trans-muconic acid were minor metabolites found in urine. Following the synthesis of ${ }^{14} \mathrm{C}$-benzene, and the preparation of pure benzene for the first time in 1952, Parke and Williams ${ }^{22}$ undertook a quantitative study of the metabolism of this chemical in rabbits. They confirmed that the major metabolites, excreted in the urine, were phenylsulphate and phenylglucuronide, with smaller amounts of the sulphate and glucuronide conjugates of quinol and catechol, and even smaller amounts of phenylmercapturic acid and trans-trans-muconic acid. They also found evidence for the further oxidation of the ring scission products to two-carbon fragments that became incorporated into the animal tissues, and were also completely oxidised to respiratory $\mathrm{CO}_{2}$. They concluded that the metabolism of benzene is a multistep process and fig 1 shows the major pathways.

Incubation of ${ }^{14} \mathrm{C}$-benzene with mouse liver microsomes in the presence of NADPH resulted in its metabolism by ring opening to give trans, transmuconaldehyde ${ }^{23}$ a direct acting alkylating agent, ${ }^{24}$ which is further metabolised to trans, trans-muconic acid..$^{25}$ trans, trans-Muconic acid is a good indicator of benzene exposure, and may be quantified in urine by high pressure liquid chromatography, with a sensitivity of $0.1 \mathrm{mg} / \mathrm{l}$; exposure of workers to benzene at $5 \mathrm{ppm}$ resulted in urine concentrations of 3$8 \mathrm{mg} / \mathrm{l}^{26}$

${ }^{14} \mathrm{C}$-Benzene is metabolised by rat liver microsomes to reactive intermediates that bind 
<smiles>CC(=O)NC(CSc1ccccc1)C(=O)O</smiles>

L - Phenylmercapturic acid<smiles>CC1(S)C=CC=CC1(O)[AsH2]</smiles>

Phenyl premercapturic acid<smiles>C[13CH]</smiles><smiles>Cc1ccccc1</smiles>

Benzene<smiles>C1=CC2OC2C=C1</smiles>

Benzene oxide<smiles>CC1(O)C=CC=CC1(C)O</smiles>

Benzene diol<smiles>Oc1ccc(O)c(O)c1</smiles>
1,2,4 - Trihydroxybenzene

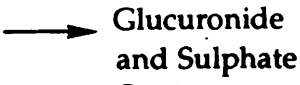

Conjugates

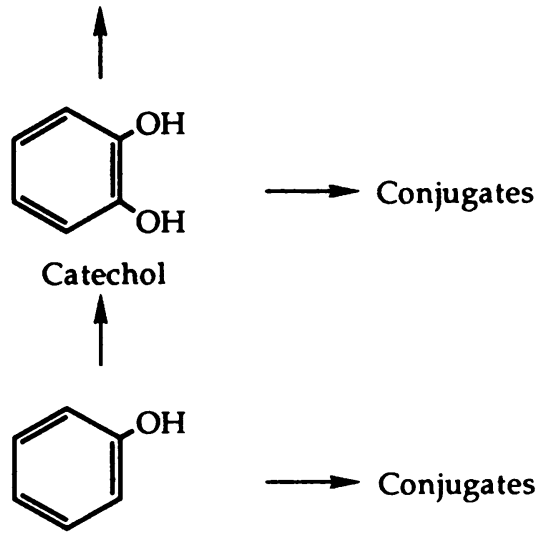

Phenol<smiles>O=C(O)c1ccc(O)cc1O</smiles>

$\longrightarrow$ Conjugates<smiles>CC(C=CC=O)=CC=O</smiles>

trans - trans - Muconaldehyde<smiles>CC=CC=CC(=O)O</smiles>

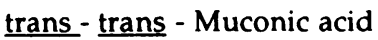

p-Benzoquinone

Figure 1 The major pathways of benzene metabolism. Formulae in parentheses are postulated intermediates.

irreversibly to microsomal protein. ${ }^{27}$ Prostaglandin $\mathrm{H}$ synthase, an enzyme with both peroxidase and cyclooxygenase activity, which is known to oxidatively activate many carcinogens and toxic chemicals-for example, benzo(a)pyrene and paracetamol-in a process known as co-oxidation, is also capable of oxidising phenolic metabolites of benzene to reactive metabolites, which bind to protein and DNA. ${ }^{28}$ The cytochrome P450 dependent oxidation of benzene to phenol and its activation to covalently binding reactive intermediates are mediated by hydroxyl radicals; biphenyl is also formed indicating the formation of a hydroxycyclohexadienyl radical as an intermediate.$^{29}$ Benzene is a substrate of cytochrome P450IIE1, a microsomal cytochrome with a propensity for generating reactive 
oxygen radicals, which is believed to effect the oxygenation of substrates by the generation of hydroxyl radicals. ${ }^{29}$ Ethanol is also metabolised by this particular cytochrome and, like benzene and other substrates, leads to induction of this cytochrome with consequent increase in oxygen radical generation that may account for the radiomimetic toxicity of this chemical.

Metabolism of ${ }^{14} \mathrm{C}$-benzene to phenol, quinol, and their conjugates by liver slices and microsomal preparations occurred at similar rates with tissue from mouse, rat, and man, but covalent binding of ${ }^{14} \mathrm{C}$-reactive metabolites to microsomal protein was in the order man $>$ mouse $>$ rat. ${ }^{30}$ In mice, metabolism to quinol glucuronide and trans, transmuconic acid (markers of toxic pathways of benzene metabolism) was proportionately greater at lower dosage; in rats a similar trend was seen, and although quinol glucuronide is a minor metabolite in rats at all doses, trans, trans-muconic acid formation was proportionately greater at lower doses. ${ }^{31}$ The pathways of detoxication of benzene in rodents are characterised by low affinity and high capacity, whereas the pathways leading to putative toxic metabolites have high affinity and low capacity, so that the use of high dose metabolism studies in rodents for assessment of the health risk to man of exposure to low doses of benzene could lead to an underestimate. ${ }^{32}$

\section{Molecular pathology of benzene poisoning}

Hypotheses as to the mechanism of benzene toxicity have been the subject of much research and debate, but there seems little doubt that multiple mechanisms are involved; these may include synergism between different metabolites, such as quinol and muconaldehyde as suggested by Snyder et $a^{33}$ or synergism between glutathione-depleting metabolites of benzene and hydroxyl radicals. Indeed, the formation of DNA adducts from reactive metabolites of benzene may be of minor importance, as the indications are that benzene and its metabolites are only weakly genotoxic, at least in man..$^{34}$

Benzene is metabolically activated via phenol to quinol and then to its oxidation products p-benzosemiquinone and p-benzoquinone, which may covalently bind to glutathione, proteins, or other cellular macromolecules (fig 2). ${ }^{36}$ The bone marrow toxicity and micronucleus formation in mice treated with benzene were inhibited by simultaneous administration of the cyclooxygenase inhibitor, indomethacin, indicating a role for prostaglandin $H$ synthase in benzene myelotoxicity possibly by co-oxygenation of phenolic metabolites to p-benzoquinone. ${ }^{37}$ The metabolism of benzene by ring opening yields trans, trans-muconaldehyde ${ }^{23}$ which is a direct alkylating agent interacting with cellular thiol and amino groups, and is a potent bone marrow toxin in mice ${ }^{24} 38$ (fig 2). Increased production of hydroxyl radicals has been shown to occur in rats dosed with benzene, ${ }^{39}$ and may arise from redox cycling of p-benzoquinone, induction of cytochrome P450IIE1, which has a propensity to generate oxygen radicals, or depletion of endogenous glutathione by $\mathrm{p}$-benzoquinone or trans, trans-muconaldehyde (fig 2).

Although Snyder $e$ al $^{33}$ have been able to show the formation of DNA adducts of benzene metabolites in the bone marrow of rats dosed orally with benzene ( $1 \mathrm{ml} / \mathrm{kg}$ daily for four days) by a ${ }^{32} \mathrm{P}$-post-labelling technique, a nuclease ${ }^{32} \mathrm{P}$-post-labelling assay with a sensitivity of detecting one adduct in $10^{9-10}$ DNA nucleotides was able to show only four lesions per $10^{9}$ DNA nucelotides in rats dosed with $200-500 \mathrm{mg} / \mathrm{kg}$ of benzene daily for five days a week for up to 10 weeks, and this only in the Zymbal gland; no adduct formation was detected in liver, kidney, bone marrow, or mammary gland in this more detailed study, and no benzene metabolite led to DNA adduct formation in any tissue. ${ }^{40}$ It has been suggested that DNA damage results from peroxidase oxidation of phenol and quinol to p-benzoquinone, which is known to damage DNA, and to result in induction of micronuclei in human lymphocytes in vitro. ${ }^{17}$ Benzene has also been shown to activate protein kinase c, an enzyme playing a pivotal part in signal transduction, which is involved in cell transformation and tumour promotion..$^{41}$ Thus both genotoxic and nongenotoxic mechanisms of carcinogenicity are evoked by benzene and its metabolites, so providing mechanistic evidence for the potential tumorigenicity of benzene.

DNA synthesis in a mouse lymphoma cell line was inhibited by p-benzoquinone $>$ quinol $>1,2,4-$ benzenetriol $>$ catechol $>$ phenol, but not by benzene itself, by a redox-type mechanism; the ease of oxidation of the benzene metabolites correlated with their $\mathrm{ED}_{50}$ values for inhibition of DNA synthesis (fig 2). ${ }^{42}$ Benzene and its metabolites, phenol, quinol, and p-benzoquinone have also been shown to inhibit RNA synthesis in macrophages and may thus inhibit haematopoiesis. ${ }^{43}$ Other studies, notably by Irons et $\mathrm{al}^{44}$ show that benzene and its metabolites can effect cell maturation in that the metabolites are able to suppress the synthesis of various cellular proteins as well as DNA and RNA.

Benzene shares certain characteristics with colchicine and the vinca alkaloids, which interfere with microtubular assembly and mitotic spindle formation and result in an arrest of cycling cells in the G2/ $M$ phase of the cell cycle. Benzene toxicity is associated with the dihydroxy metabolites, catechol and quinol, which concentrate in the bone-marrow; quinol and its oxidation product, p-benzoquinone, interfere with microtubule assembly and react with nucleophilic sulphydryl groups that are essential for the binding of guanosine triphosphate to tubulin, 


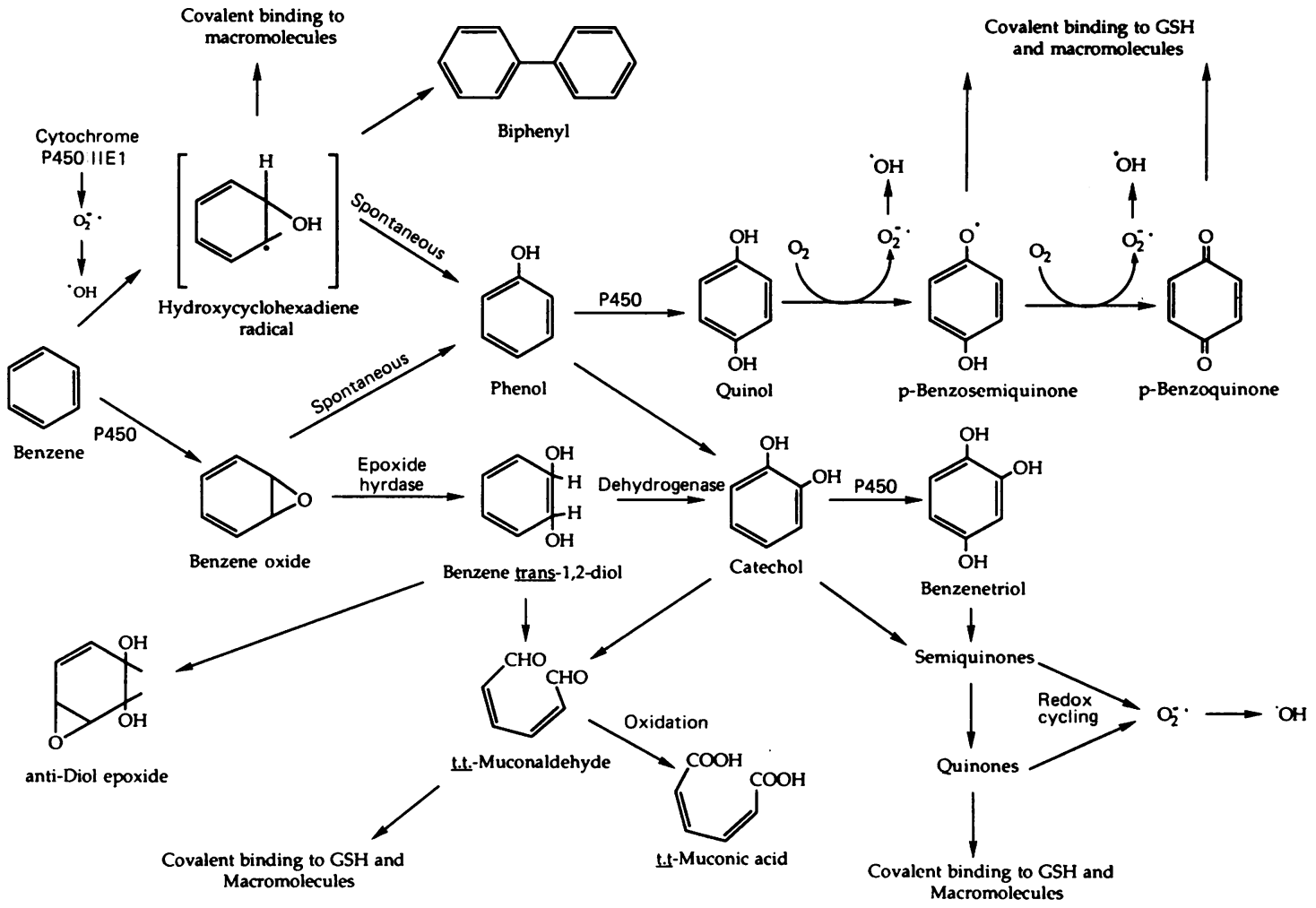

Figure 2 Molecular mechanism of benzene toxicity/carcinogenicity. p-Benzoquinone, p-benzosemiquinone, other quinones, malondialdehyde, and radical metabolites may covalently bind to glutathione and intracellular macromolecules. Oxygen radicals may be produced by redox cycling with the benzoquinones, or from cytochrome P450 IIE1, which is induced by benzene.

resulting in the arrest of cell division and suppression of lymphocyte blastogenesis. ${ }^{45}$ Benzene and its metabolites kill cells undergoing cell division, but spare resting cells by a mechanism as yet not defined; however, it seems plausible that the cytogenetic effects associated with benzene, which are primarily chromosomal gaps and chromosomal breaks, may play a part. ${ }^{13}$

The pattern of benzene associated bone marrow toxicity has been reproduced by the coadministration of two benzene metabolites-namely, phenol and quinol-although neither of these compounds administered alone produced significant myelosuppression, ${ }^{46}$ thus confirming the previous observations of Tunek et al. ${ }^{47}$ When phenol and quinol were coadministred to mice by a "continuous" regimen, bone marrow cellularity decreased initially, with gradual recovery beginning at the second week despite continued treatment. When the mice were treated by a "discontinuous" regimen, however, bone marrow cellularity decreased profoundly, with no evidence of recovery during the treatment period. This apparent paradox, in which the lower total dose administered in the "discontinuous" protocol was more toxic than the higher dose of the "continuous" regimen, supports the view that the toxic effect of benzene metabolites on the marrow was cycle dependent. Supportive evidence of this came from the studies of Luke $e t$ al $^{\mathbf{4 8}}{ }^{49}$ who found that a three day exposure regimen produced more micronucleated polychromatic erythrocytes than did five days of exposure.

Finally, a series of studies have shown that benzene affects the function of the cellular and hormonal regulators of blood formation, in particular, the function of the stromal cell. ${ }^{5051}$ This effect appears to be due to a selective suppression of IL-1 released by macrophages, which in the case of the benzeneassociated suppression of pre-B lymphocytes, results in a reduction of IL-1 dependent release of IL-4 by marrow fibroblasts. ${ }^{52}$ Thus the haemotoxic effects of benzene, and its cytotoxicity, genotoxicity, and car- 
cinogenicity, are clearly the consequences of a number of highly complex, interactive biological processes.

\section{Risk assessment}

The PEL in the United States and the United Kingdom for many years was $10 \mathrm{ppm}\left(32 \mathrm{mg} / \mathrm{m}^{3}\right)$, but this was recently lowered to $1 \mathrm{ppm}$ in the United States and $5 \mathrm{ppm}$ in the United Kingdom. Benzene is no longer used as a general solvent in the United States, the United Kingdom, and other European countries, but it is still widely used as an industrial solvent in China where the present exposure limit is $40 \mathrm{mg} / \mathrm{m}^{3}(12.5 \mathrm{ppm})$; of more than 50000 work places in China the mean concentration of benzene was $5.5 \mathrm{ppm}$. In more than 500000 workers in China exposed to benzene or benzene mixtures the prevalence of benzene poisoning was $0 \cdot 5 \% .{ }^{53}$ In a 35 year longitudinal study of the haematological surveillance records of 459 rubber workers exposed to benzene, strong positive correlations were found between blood count fluctuations and fluctuations in exposure to benzene for the earlier periods of observation (1940-8, average exposures were $75 \mathrm{ppm}$ ) but not for later years (1948-75, average exposures were $15-20 \mathrm{ppm})^{54}$; estimates of the risk of leukaemia related to occupational exposure to benzene for a working lifetime ( 40 to 45 years) were 9.5174 cases/ 1000 workers for exposures to $10 \mathrm{ppm}$, and 5-14 cases/1000 workers for exposures to $1 \mathrm{ppm}$. The lifetime cancer risk recently calculated from a pharmacokinetically derived risk assessment based on rodent data with scaling across species gave 6-14 cases/1000 workers for exposure to benzene at $10 \mathrm{ppm} .^{55}$ From a consideration of benzene metabolism to model the internal dose, from the administered dose in animal studies, and fitting a multistage risk assessment model, Bailer and $\mathrm{Hoel}^{56}$ calculated that a $1 \mathrm{ppm}$ lifetime exposure would result in 0.7-1.0 excess cancers per 1000 persons exposed.

In a recent review and update of leukaemia risk associated with exposure to benzene it was concluded that the cohort of Rinsky et $a l^{57}$ provides the best basis for estimation of the benzene associated risk of leukaemia, and that no other available study is suitable for assessment of risk. ${ }^{58} \mathrm{Re}$-evaluation of the data indicates that past assessments may have overestimated the risk by a factor of three to 24 and, based on the data of Rinsky $e t a^{57}$ and exposure matrices of Crump and Allen ${ }^{59}$ an estimate of 7.9 excess leukaemia deaths per 1000 workers exposed for 45 years to $10 \mathrm{ppm}$ of benzene, and an excess of 0.5 leukaemia deaths per 1000 workers exposed for 45 years to $1 \mathrm{ppm}$, were proposed..$^{58}$ Examination of the data of Rinsky et $a l^{57}$ which are based on nine leukaemia related deaths, shows that three cases had cumulative exposure between 470-640 ppm-years, two cases had cumulative exposure between 250 and $260 \mathrm{ppm}$ - years, and the remaining four cases had cumulative exposures of $99,50,10$, and $0 \cdot 1 \mathrm{ppm}$-years, that is, effectively three different data points. Rinsky et $a^{57}$ stated that the shape of the best fit model was linear. If the observed and predicted probabilities of leukaemia are examined, however, the data are seen to be polarised into three areas, with the response at lower levels being relatively flat. Thus, in the risk assessment of Rinsky et al, ${ }^{57}$ it is the three highest exposure cases that drive the model. When using a conditional logistic regression to predict the probability of leukaemia at a given level of exposure, with the three high cases included, the model was significant $\left(\chi^{2}=13.3, \mathrm{p}<0.01\right)$; after removal of the three cases (and their control), however, the model was not significant $\left(\chi^{2}=1.4, p=0.23\right)$. Furthermore, the estimates of exposure, as highlighted in the study, were considered to be an underestimate, ${ }^{57}$ and underestimation of exposure would increase the predicted risk at any given exposure. A further confusing factor is that multiple myeloma was the cause of death in four members of the Rinsky cohort of benzene workers, ${ }^{57}$ three of the four were among the group with the lowest cumulative exposure to benzene ( $<40 \mathrm{ppm}$-years), and all four required an exceptionally long latency period $\left(>20\right.$ years).$^{60}$ These two factors indicate a possibility that low cumulative exposure to benzene may result in well differentiated malignancy such as multiple myeloma, whereas higher exposures lead to leukaemia. ${ }^{60}$ This observation confuses even further the risk assessment procedure for occupational and environmental exposure to benzene, for if true it might justify the recent ACGIH proposal for a decrease in the TLV for benzene to $0 \cdot 1 \mathrm{ppm}$.

The risk assessment for exposure of man to low concentrations of benzene is based on few cases (nine) ${ }^{58}$ Furthermore, it is difficult to explain the observed different disease end points in relation to low level exposure and duration of such exposure, as described by Rinsky, ${ }^{60}$ unless different mechanisms of toxicity/carcinogenicity at different levels and durations of exposure are postulated. This complicates any assessment of risk and is likely to lead to overestimation of such risks. Examination of relevant, non-epidemiological experimental data shows a negative effect of benzene-but not of its toxic metabolites-in the Ames and other genotoxicity tests that depend on activation systems such as the Aroclor-induced rat liver S9 mix, possibly indicating the involvement of cytochromes other than the Aroclor-induced P450IA1 and P450IIB in the metabolic activation of benzene. The data are further complicated by the known induction by benzene of P450IIE1, an oxygen radical generator, the high susceptibility of rodents to oxygen, ${ }^{61}$ and the vulnerability of isolated cell systems to oxygen toxicity because of depletion of glutathione and other 
components of the biological anti-oxidant defence system. The reasons for toxicity and carcinogenicity of benzene are thus complex, involving several different mechanisms ( $p$-benzoquinone covalent binding, trans, trans-muconaldehyde depletion of glutathione, oxygen radical production by redox cycling from p-benzosemiquinone, and induction of cytochrome P450IIE) all possibly associated with different disease endpoints (haemotoxicity, leukaemia, multiple myeloma), and probably related to individual susceptibility (genetic, dietary, smoking, alcohol consumption). Given that this is the case, then regulators should proceed with caution when making judgements on acceptable limits of exposure, based on an inadequate data base in man and using such epidemiological risk models as described in this review.

Requests for reprints to: Professor D V Parke, Department of Biochemistry, University of Surrey, Guildford, Surrey GU2 5XH, UK.

1 Kalf GF. Recent advances in the metabolism and toxicity of benzene. CRC Crit Rev Toxicol 1987;18:141-59.

2 Howard PH, Durkin PR. Sources of contamination, ambient levels and fate of benzene in the environment. Washington, DC: U.S. Environmental Protection Agency, 1974. (EPA 560/5-75005.)

3 Snyder R, Longacre SL, Witmer CM, Kocsis JJ. Biochemical toxicology of benzene. Reviews of Biochemical Toxicology 1981;3:123-53.

4 Huff JE, Haseman JK, De Marini DM, et al. Multiple-site carcinogenicity of benzene in Fischer 344 Rats and B6 C3F1 mice. Environ Health Perspect 1989;82:125-63.

5 Anon. Notice of Intended changes-Benzene. Applied Occupational and Environmental Hygiene 1990;5:453-63.

6 Delore P, Borgomano C. Leucémie aigüe au cours de l'intoxication benzénique. Sur l'origine toxique de certaines leucémies aigües et leurs rélations avec les anémies graves. Journal de Médecine de Lyon 1928;9:227-33.

7 Aksoy M. Benzene as a leukemogenic and carcinogenic agent. Am J Ind Med 1985;8:9-20.

8 Davies JE, Levine RS. Human health effects of benzene. In: Benzene in Florida Groundwater: An Assessment of the Significance to Human Health. Washington DC: American Petroleum Institute, 1986:16-35.

9 Van Raalte HGS. A critical look at hazards from benzene in workplace and community air. Regul Toxicol Pharmacol 1982;2:67-76.

10 International Agency for Research on Cancer. Monographs on the evaluation of carcinogenic risks to humans. Overall evaluations of carcinogenicity: An updating of IARC Monographs, suppl 7. Vols 1-42. Benzene 120-122. Lyon: IARC, 1987.

11 Vigliani EC. Leukaemia associated with benzene exposure. In: Occupational Carcinogenesis. Ann NY Acad Sci 1976; 271:143-51.

12 Maltoni C, Ciliberti A, Cotti G, Conti B, Belpoggi F. Benzene, an experimental multipotential carcinogen: Results of the long-term bioassays performed at the Bologna Institute of Oncology. Environ Health Perspect 1989;82:109-24.

13 Dean BJ. Recent findings on the genetic toxicology of benzene, toluene, xylenes and phenols. Mutat Res 1985;154:153-81.

14 Glatt $\mathrm{H}$, Witz G. Studies on the induction of gene mutations in bacterial and mammalian cells by the ring-opened benzene metabolites trans, trans-muconaldehyde and trans, transmuconic acid. Mutagenesis 1990;5:263-6.

15 Pellack-Walker P, Blumer JL. DNA damage in L5178Y cells following exposure to benzene metabolites. Mol Pharmacol 1983;30:42-7.

16 Morimoto K, Wolff S, Koizumi A. Induction of sister-chromatid exchanges in human lymphocytes by microsomal activation of benzene metabolites. Mutat Res 1983;119:355-60.

17 Smith MT, Yager JW, Steinmetz KL, Eastmond DA. Peroxidase-dependent metabolism of benzene's phenolic metabolites and its potential role in benzene toxicity and carcinogenicity. Environ Health Perspect 1989;82:23-9.

18 Witz G, Gad SC, Tice, RR, Oshiro Y, Piper CE, Goldstein BD. Genetic toxicity of the benzene metabolite trans, transmuconaldehyde in mammalian and bacterial cells. Mutat Res 1990;240:295-306.

19 Erexson GL, Wilmer JL, Kligerman AD. Sister chromatid exchange induction of human lymphocytes exposed to benzene and its metabolites in vitro. Cancer Res 1985;45:2471-7.

20 Glatt H, Padykula R, Berchtold GA, et al. Multiple activation pathways of benzene leading to products with varying genotoxic characteristics. Environ Health Perspect 1989;82:81-9.

21 Parke DV. Introduction: Session on metabolism. Environ Health Perspect 1989;82:7-8.

22 Parke DV, Williams RT. Studies in detoxication. 49. The metabolism of benzene containing $\left[{ }^{14} \mathrm{C}\right]$ benzene. Biochem $J$ 1953;54:231-8.

23 Latriano L, Goldstein BD, Witz G. Formation of muconaldehyde, an open-ring metabolite of benzene, in mouse liver microsomes: An additional pathway for toxic metabolites. Proc Nat Acad Sci USA 1986;83:8356-60.

24 Witz G, Latriano L, Goldstein BD. Metabolism and toxicity of trans, trans-muconaldehyde, an open-ring microsomal metabolite of benzene. Environ Health Perspect 1989;82: 19-22.

25 Witz G, Maniara W, Mylavarapu V, Goldstein GD. Comparative metabolism of benzene and trans, trans-muconaldehyde to trans, trans-muconic acid in DBA/2N and C57BL/6 mice. Biochem Pharmacol 1990;40:1275-80.

26 Inoue $\mathrm{O}$, Seiji $\mathrm{K}$, Nakatsuka $\mathrm{H}$, et al. Urinary $\mathrm{t}, \mathrm{t}$-muconic acid as an indicator of exposure to benzene. $\mathrm{Br} J$ Ind Med 1989; 46:122-7.

27 Tunek A, Platt KL, Bentley P, Oesch F. Microsomal metabolism of benzene to species irreversibly binding to microsomal protein and effects of modifications of this system. Mol Pharmacol 1978;14:920-9.

28 Schlosser MJ, Shurina RD, Kalf GF. Metabolism of phenol and hydroquinone to reactive products by macrophage peroxidase or purified prostaglandin $\mathrm{H}$ synthase. Environ Health Perspect 1989;82:229-37.

29 Johansson I, Ingelman-Sundberg $M$. Hydroxyl radicalmediated cytochrome P-450-dependent metabolic activation of benzene in microsomes and reconstituted systems from rabbit liver. J Biol Chem 1983;258:7311-16.

30 Brodfuehrer JI, Chapman DE, Wilke TJ, Powis G. Comparative studies of the in vitro metabolism and covalent binding of ${ }^{14} \mathrm{C}$ benzene by liver slices and microsomal fraction of mouse, rat and human. Drug Metab Dispos 1990;18:20-7.

31 Sabourin PJ, Bechtold WE, Griffith WC, Birnbaum LS, Lucier G, Henderson RF. Effect of exposure concentration, exposure rate, and route of administration on metabolism of benzene by F344 rats and B6C3F1 mice. Toxicol Appl Pharmacol 1989; 99:421-44.

32 Henderson RF, Sabourin PJ, Bechtold WE, et al. The effect of dose, dose rate, route of administration, and species on tissue and blood levels of benzene metabolities. Environ Health Perspect 1989;82:9-17.

33 Siyder R, Dimitriadis E, Guy R, et al. Studies on the mechanism of benzene toxicity. Environ Health Perspect 1989;82:31-5.

34 Yardley-Jones A, Anderson D, Jenkinson PC, Lovell DP Blowers SD, Davis MJ. Genotoxic effects in peripheral blood and urine of workers exposed to low level benzene. Br J Ind Med 1988;45:694-700.

35 Yardley-Jones A, Anderson D, Lovell DP, Jenkinson PC. Analysis of chromosomal aberrations in workers exposed to low level benzene. $B r J$ Ind Med 1990;47:48-51.

36 Tunek A, Platt KL, Przybylski M, Oesch F. Multistep metabolic activation of benzene. Effect of superoxide dismutase on covalent binding to microsomal macromolecules, and identification of glutathione conjugates using high pressure liquid chromatography and field desorption mass spectrometry. Chemico-Biological Interactions 1980;33:1-17.

37 Kalf GF, Schlosser MJ, Renz JF, Pirozzi SJ. Prevention of benzene-induced myelotoxicity by nonsteroidal anti-inflammatory drugs. Environ Health Perspect 1989;82:57-64.

38 Witz G, Rao GS, Goldstein BD. Short-term toxicity of trans, trans-muconaldehyde. Toxicol Appl Pharmacol 1985;80: $511-6$.

39 Khan S, Krishnamurthy R, Pandya KP. Generation of hydroxyl radicals during benzene toxicity. Biochem Pharmacol 1990;39:1393-5. 
40 Reddy MV, Blackburn GR, Schreiner CA, Mehlman MA Mackerer CR. ${ }^{32} \mathrm{P}$ Analysis of DNA adducts in tissues of benzene-treated rats. Environ Health Perspect 1989;82:253-7.

41 Da Silva C, Fan X, Castagna M. Benzene-mediated protein kinase c activation. Environ Health Perspect 1989;82:91-5.

42 Pellack-Walker P, Walker JK, Evans HH, Blumer JL. Relationship between the oxidation potential of benzene metabolites and their inhibitory effect on DNA synthesis in L5178YS cells. Mol Pharmacol 1985;28:560-6.

43 Post G, Snyder R, Kalf GF. Metabolism of benzene and phenol in macrophages in vitro, and the inhibition of RNA synthesis by benzene metabolites. Cell Biology and Toxicology $1986 ; 2: 231-46$.

44 Irons RD, Heck H d'A, Moore BJ, Muirhead KH. Effects of short-term benzene administration on bone marrow cell kinetics in the rat. Toxicol Appl Pharmacol 1979;51:399-409.

45 Irons RD. Quinones as toxic metabolites of benzene. J Toxicol Environ Health 1985;16:673-8.

46 Eastmond DA, Smith MT, Irons RD. An interaction of benzene metabolites reproduces the myelotoxicity observed with benzene exposure. Toxicol Appl Pharmacol 1987;91:85-95.

47 Tunek A, Olofsson T, Berlin M. Toxic effects of benzene and benzene metabolites on granulopoietic stem cells and bone marrow cellularity in mice. Toxicol Appl Pharmacol 1981:59:149-56.

48 Luke CA, Tice RR, Drew RT. The effect of exposure regimen and duration on benzene-induced bone marrow damage in mice. I. Sex comparison in DBA/2 mice. Mutat Res 1988;203:251-71.

49 Luke CA, Tice RR, Drew RT. The effect of exposure regimen and duration on benzene-induced bone marrow damage in mice. II. Strain comparisons involving B6CF1, C57B1/6 and DBA/2 male mice. Mutat Res 1988;203:273-95.

50 Gaido KW, Wierda D. Modulation of stromal cell function in $\mathrm{DBA} / 2 \mathrm{~J}$ and $\mathrm{B} 6 \mathrm{C} 3 \mathrm{~F} 1$ mice exposed to benzene or phenol. Toxicol Appl Pharmacol 1985;81:469-75.

51 Gaido KW, Wierda D. Suppression of bone marrow stromal cell function by benzene and hydroquinone is ameliorated by indomethacin. Toxicol Appl Pharmacol 1987;89:378-90.

52 King AG, Landreth KS, Wierda D. Hydroquinone inhibits bone marrow pre-B cell naturation in vitro. Mol Pharmacol 1988;32:807-12.

53 Yin S-N, Li Q, Liu Y, Tian F, Du C, Jin C. Occupational exposure to benzene in China. Br J Ind Med 1987;44:192-5.

54 Kipen HM, Cody RP, Crump KS, Allen BC, Goldstein BD. Haematological effects of benzene: A thirty-five year longitudinal study of rubber workers. Toxicol Ind Health 1988;4:411-30.

55 Beliles RP, Totman LC. Pharmacokinetically based risk assessment of workplace exposure to benzene. Regul Toxicol Pharmacol 1989;9:186-95.

56 Bailer AJ, Hoel DG. Metabolite-based internal doses used in a risk assessment of benzene. Environ Health Perspect 1989;82:177-84.

57 Rinsky RA, Smith AB, Hornung R, et al. Benzene and leukaemia. An epidemiologic risk assessment. $N$ Engl J Med 1987;316:1044-50.

58 Brett SM, Rodricks JV, Cinchilli VM. Review and update of leukaemia risk potentially associated with occupational exposure to benzene. Environ Health Perspect 1989;82:267-81.

59 Crump KC, Allen BC. Quantitative estimates of the risk of leukaemia from occupational exposure to benzene. Washington, DC. Prepared for the Occupational Safety and Health Administration, May 1984.

60 Rinsky RA. Benzene and leukaemia: An epidemiologic risk assessment. Environ Health Perspect 1989;82:189-91.

61 Parke DV, Ioannides C. Roles of cytochromes P-450 in mouse liver tumour production. In: Stevenson DE, McClain RM, Popp JA, Slaga TJ, Ward JM, Pitot HC, eds. Mouse liver carcinogenesis: mechanisms and species comparisons. New York: Alan R Liss, 1990:215-30.

Accepted 14 January 1991

From 1 July 1985 articles submitted for publication will not be returned. Authors whose papers are rejected will be advised of the decision and the manuscripts will be kept under security for three months to deal with any inquiries and then destroyed. 